\title{
Perspectives
}

\section{Discourses, Practices, and Realities of Multilingualism in Higher Education}

\section{Hyunjung Shin E Andrea Sterzuk}

This Perspectives article explores the changing sociolinguistic realities of Canadian postsecondary institutions focusing on tensions and contradictions around two prominent discourses: internationalization and indigenization of higher education. In doing so, we focus on a common challenge: English dominance in Canadian universities. This linguistic hegemony persists in a time of Truth and Reconciliation and indigenization of education as well as within the intensified discourse of internationalization in the new global political economy. As professors of language education in two prairie province universities, we draw on examples from our own contexts and consider the potential mismatches between positive discourses about multilingualism and practices and structural realities that do not support on-the-ground multilingualism. We situate our discussion within a larger social, political economic context of contemporary colonialism and capitalism. Our goal is to introduce a critique of the ongoing role Canadian universities play in producing settler colonialism and English monolingualism as well as to provide suggestions to engage more meaningfully with multilingualism in today's higher education across Canada.

Cet article de Perspectives explore l'évolution des réalités sociolinguistiques des établissements postsecondaires canadiens en mettant l'accent sur les tensions et les contradictions qui entourent deux discours très répandus: l'internationalisation et l'autochtonisation de l'enseignement supérieur. Dans ce cadre, nous nous concentrons sur un défi commun : la dominance de la langue anglaise dans les universités canadiennes. Cette hégémonie linguistique persiste à une époque caractérisée par des notions de Vérité et Réconciliation et d'autochtonisation de l'éducation, et elle s'inscrit également dans un discours intensifié d'internationalisation au sein de la nouvelle économie politique mondiale. Professeures de langues dans deux universités différentes des Prairies canadiennes, nous nous appuyons sur des exemples tirés de nos propres contextes et nous penchons sur les possibilités d'inadéquation entre des discours positifs sur le multilinguisme et des pratiques et des réalités structurelles qui ne soutiennent pas le multiculturalisme sur le terrain. Nous inscrivons notre discussion dans le contexte plus large $d u$ colonialisme et du capitalisme contemporains. Notre objectif est d'entamer une critique du rôle que les universités canadiennes continuent de jouer dans la production d'un colonialisme de peuplement et d'un monolinguisme anglophone, 
et également de fournir des suggestions en faveur d'un engagement plus significatif envers le multiculturalisme dans l'enseignement supérieur actuel à travers le Canada.

KEYWORDS: multilingualism, higher education, international students, Indigenous languages, globalization

\section{Introduction}

This Perspectives article presents our personal and professional incidents as a starting point to provide a more comprehensive conceptual discussion of the sociolinguistic realities of Canadian universities. We focus broadly on lessons learned from our professional experiences to (a) introduce a critique of the ongoing role Canadian universities play in producing settler colonialism and English monolingualism, and (b) imagine meaningful engagement with multilingualism in Canadian higher education (HE). In pursuit of these goals, we focus on tensions and contradictions surrounding two prominent discourses: internationalization and indigenization of HE as well as their interactions with multilingualism, which we understand as a wide variety of sociolinguistic practices related to the construction of social difference and social inequality under contemporary historical conditions (Heller, 2007).

As terms, both internationalization and indigenization represent policies and practices designed to transform Canadian universities. In the case of internationalization, the transformations intend to respond to globalization (Altbach \& Knight, 2007) and typically include activities such as curricular changes; targeted recruitment of international students; and development of international education programs for domestic students, faculty, and staff (Bartell, 2003). In the case of indigenization, the transformations intend to respond to the ongoing effects of settler colonialism and theoretically constitute a resistance to, and a dismantling of, settler-colonial systems. So far, much of indigenization practices of Canadian universities fall under Indigenous inclusion (Gaudry \& Lorenz, 2018), where Indigenous students, faculty, and staff are provided additional supports to succeed within the existing system. At the other end of the spectrum, the university commits to fundamental transformation because it engages deeply with Indigenous Peoples, intellectuals, and Indigenous knowledge systems (Gaudry \& Lorenz, 2018). Internationalization and indigenization do not produce the same types of language-related issues or agendas in Canadian universities. Yet, because Indigenous languages are often grouped with non-official settler or immigrant languages in discussions of multilingualism, we choose to address the priorities and complexities engendered by both processes within this article.

Indeed, the term "multilingualism" may not be the best fit for this article, but it is a widely used term in Canadian HE as an aspired norm, and so we 
use it in our writing. Part of our concerns with the term is our recognition that the status, needs, and realities of Indigenous languages and those of other non-official languages are different from each other (Haque \& Patrick, 2015; McIvor \& Anisman, 2018; St. Denis, 2011). Therefore, it is impossible to group these languages under umbrella terms such as multilingualism or linguistic diversity. Indeed, it may be more productive to consider using "language related inequalities" instead of "multilingualism" as a way of expressing issues around language related to both Indigenous and international students. The relationships between internationalization, indigenization, and multilingualism in Canadian universities are also complex. For example, internationalization has the effect of diversifying the range of possible linguistic repertoires of students (Marshall, 2009; Marshall et al., 2012). A main concern for our critique is that these student linguistic resources are often ignored or treated as problematic. In terms of indigenization and language, it is important to recognize that many Canadian universities have a long history of Indigenous language programs. In Saskatchewan, for example, Indigenous languages have been included as credit courses in universities for well over 30 years. However, whereas language courses in the 1980s may have been "taught to a mixed classroom of fluent and non-fluent speakers" (Lewis et al., 2018), community language shift today means that many Indigenous students in Canadian universities are not fluent speakers, and their language needs may have changed. Canadian universities have a responsibility to work toward meeting these changing needs through a range of possible programs and approaches.

In some ways, both processes should push HE to plan for languages other than English and French as languages of instruction and assessment and subjects of study. Yet, with some exceptions, Canadian campuses continue to function as sites of English (or French) monolingualism, and efforts to transform the academy remain entangled with processes of settler colonialism, racialization, and resource accumulation. Detangling the relationship between internationalization, indigenization, and their competing impact on the realities of multilingualism (and monolingualism) in Canadian HE is not easy. What is a shared trait, however, is the obstacle of English dominance created by ongoing systems of settler colonialism that often work to flatten linguistic difference through education systems (Sterzuk 2011, 2015, Sterzuk \& Fayant, 2016). If Canadian universities want to increase space for Indigenous languages as languages of teaching and learning and also determine ways to incorporate other non-official languages as legitimate resources in classroom contexts, fundamental transformation of a dominant notion of multilingualism as the co-existence of multiple sets of monolingualism (Heller \& McElhinny, 2017) is required.

We recognize that our own identities shape our discussion. We are both female professors of language education in Saskatchewan, and neither of us identifies as Indigenous. Hyunjung grew up in South Korea and has lived in multiple regions of Canada as an international student and as an immigrant. 
Andrea is a white settler woman who grew up as an English monolingual in Saskatchewan and learned several additional languages as an adult. Drawing on examples from our personal and professional contexts, we first consider the potential mismatches between, on one hand, positive discourses about multilingualism and, on the other, practices and structural realities that do not support multilingualism in the general classroom or public spaces of the university. Despite many encounters that suggest that university systems are resistant to change, we offer suggestions for policy makers and practitioners to better support the learning experiences and language repertoires of international and Indigenous students, albeit in very different ways. Before moving to lessons learned, we briefly situate our discussion within a larger social, political economic context of contemporary colonialism and capitalism.

\section{Colonialism, Capitalism, and Multilingualism in Higher Education}

Our discussion is informed by critical social theories (Bourdieu, 1991, 1998; Harvey, 2005), postcolonial theories (Loomba, 1998; Smith, 1999), and recent applied linguistics and sociolinguistics research that highlights how language is being transformed into a set of soft skills with exchange value in the labour market of the new economy (Shin \& Park, 2016; Block, 2017; Chun, 2009; Darvin \& Norton, 2015; Holborow, 2015). From this angle, language learning functions as a kind of personal self-development, language is constructed as standardized and measurable competence, and second language (L2) learning is transformed into an individual responsibility detached from the social context (Shin, 2016). This understanding of multilingualism creates challenges because in Canadian HE, the social context of language learning cannot be separated from settler colonialism (Shin \& Kubota, 2008). This contemporary intertwining of capitalism and colonialism should be understood as major producing mechanisms of language-related inequalities (Heller \& McElhinny, 2017).

For example, Haque and Patrick (2015) discuss the impact of neoliberalism on Indigenous language policy in Canada emphasizing individual needs over collective rights, which in turn prevents policy to promote Indigenous language rights and perpetuates linguistic and cultural assimilation resulting from settler colonialism and racial hierarchies of power. The influx of international students to Western universities has always been intertwined with colonialism (Pennycook, 1998) but is further accelerated by neoliberal capitalism in which public funding for $\mathrm{HE}$ is reduced with the increasing corporatization of education. Internationalization in higher education (IHE) is closely tied to this transformation in the global economy. Universities are under pressure to "brand" themselves as "global" to increase revenue and access new markets (Duchêne \& Heller, 2012; Knight, 2004; Kubota, 2009). The effectiveness of education is often assessed by its ability to provide students 
with the skills required in the labour market, with language skills being a key dimension of the skill set of ideal workers. Therefore, despite the increasingly popular discourses around translanguaging (e.g., García \& Wei, 2014), plurilingualism (e.g., Marshall \& Moore, 2013), and multilingualism in Teaching English as a second language (TESL) research, we question the degree to which these concepts and ideas inform and transform language policies and pedagogies when HE is held accountable to the labour market demand for "standardized" language skills.

In this context, colonial construction of English language teaching (ELT) re-inscribes the racialized linguistic hierarchy among the languages of Indigenous groups, immigrants and sojourners, and settlers within Canada, as well as among different varieties of English or "unequal Englishes" in the global labour market (Pennycook, 19998; Tupas, 2015). Below, we share our classroom experiences and interactions with policy to illustrate how internationalization and indigenization discourses connect through persisting English monolingualism.

\section{Persisting English Monolingualism in Canadian Higher Education}

While HE in Canada and elsewhere are increasingly multilingual spaces, universities continue to operate in ways that privilege English monolingualism. Monolingual models are inadequate for the purposes of contemporary HE where conditions of unpredictability and diversity are increasingly the norm. By unpredictability, we refer to the languages and speakers people encounter in everyday lives. Present-day conditions of mobility and technological interaction mean that learners, teachers, and staff cannot predict the language varieties they will encounter in Canadian universities. University policies and practices tend to treat these postmodern conditions in two ways: (a) as the exception or (b) as something that needs to be controlled. We further illustrate these points by offering examples from our own contexts.

Demonstrating connections between the processes of internalization and indigenization in the following examples is challenging. First, we recognize the limitations of pedagogical practice on impacting university policy. It may be unfair to ask TESL practitioners to be responsible for affecting changes beyond the classrooms, particularly when they are often under-employed and, paradoxically, already over-worked given the political economy of ELT. In some instances, it also felt as if we were guilty of tagging on "international students" or "Indigenous students" in our attempts to highlight links between these discourses and multilingualism. In part, showing connections

presents challenges because the two discourses seem to operate separately within our contexts. In reality, however, there is constant interaction between the two in terms of university decisions around budgets, allocation of resources, the development of new programs, and the hiring of instructors. 
Yet, in these neoliberal times, universities increasingly depend on international students as revenue streams. Paying attention to this fiscal reliance is important as we consider which languages are planned for in HE. We do not pretend to offer any easy solutions but we believe it is important to directly address these tensions as we call for challenges to the production of language-related inequality.

\section{Gatekeeping International Student Access to Learning}

In both our contexts, there is a spectrum of instructor responses to increased multilingualism. Some instructors are inclusive in their pedagogical practices, and others may intentionally or inadvertently prevent students from participating fully in learning. In one instance at Andrea's university, a colleague described instances of some Chinese international students being prevented from participating in group work by English monolingual Canadian classmates. In group writing assignments, the group would choose a Canadian to write the text and prevent the international classmates from contributing to the project, causing them to lose out on meaningful learning opportunities. The professor viewed this behaviour as undesirable but also validated the group's choice to distribute the work as they wished. International students need to be supported and encouraged in their academic pursuits, not restricted because their English is deemed insufficient or lacking in some way. Instances of gatekeeping such as these can have real material effects. This is also reflective of a deeper issue of institutional expectations. The "gatekeeping" students and instructors who are complicit may be preventing international students from taking a leadership role in group work (e.g., writing the project) because of the pressure of having to deliver an English product from a monolingual Western perspective (also see L2 academic discourse socialization research for similar examples ). A range of pedagogical solutions is likely possible. Some instructors may wish to provide students with the choice of whether they wish to complete assignments in a group or as individuals or to design assignments that allow students to contribute through different roles (one conducts research, another writes, and another presents). Further still, students themselves might need to be engaged in a critical discussion of English language variation, learning, and the value of participation for all students in terms of learning prior to embarking on group assignments. Finally, departmental policies designed to avoid this kind of gatekeeping might also need to be implemented to produce the kind of shift necessary to prevent instances like this from occurring.

\section{Policing of Language Variation in Written Assignments}

For different reasons, international students and Indigenous students may experience inequitable access to learning within Canadian HE (Sterzuk, 2015; Gordon \& White, 2014; Marshall, 2009; Ottman, 2017; Restoule et al., 2013). 
While not the only factor nor a universal issue for either group of students, the emphasis on academic English, or so-called Standard English, in university classrooms can be an obstacle to educational attainment. For example, we often hear faculty and staff mentioning "(English) language problems" of international students, particularly in reference to academic writing. This is not necessarily due to weaknesses in English language skills but, rather, can be symptomatic of deficit understandings of multilingualism and also because of the way that race and perceptions of English are intertwined. While the nature of accessing academic English presents differently for international students (often L2 speakers of English) and Indigenous students (usually L1 speakers of English), the vulnerability of international and Indigenous students is produced similarly because of how they can be positioned within the academy. Canadian society and Canadian HE continue to be structured as racial hierarchies that place white settler Canadians at the top, settlers of colour and undesired immigrants next, and Indigenous Peoples at the bottom (Sterzuk, 2015; Thobani, 2007). This hierarchy is intertwined with English language performance because white settler ways of speaking English remain elevated over other(ed) Englishes, particularly those Englishes connected to non-white people. Indeed, Motha (2006) describes whiteness as an "intrinsic but veiled element of the construct of mainstream English" (p. 497). Therefore, policing English language variation can be understood as symbolic investment in whiteness.

In her very first term at the university, Hyunjung was assigned to teach an Indian Teacher Education Program (ITEP) course on secondary literacy. She had lived in Canada for nearly 10 years before she moved to the current city for a faculty position but this incident was her first time teaching Indigenous students. The problematic understanding she had from previous research and teaching experiences was that Indigenous learners of English typically struggle with "written academic English" given the emphasis on oral languages in their culture. She felt that she could see this mismatch clearly in the papers her ITEP students produced. So she mentioned in class, referring to Delpit's (1988) work on the topic of the "culture of power" or the explicit and implicit rules that provide access to education (including the rules of Standard English), that while she understood their culture emphasizes oral languages, it was important for them to master the linguistic codes of power to be successful in mainstream HE (Zappa-Hollman \& Duff, 2015), and provided information regarding on-campus writing support services in that regard. After the term was over, she was shocked to read a student's comment at the end of a course evaluation that accused the instructor of making negative assumptions about First Nations culture.

This was a critical moment for Hyunjung to reflect on implicit (and explicit) policing of language variation in class assignments prevalent in Canadian universities, the focus on academic writing conventions in L2 education, and its potentially negative consequences for Indigenous students' sense of 
identity. Her attempt to support the Indigenous students' access to academic English was perceived as highlighting deficits and making assumptions about them as learners. As TESL practitioners, we need to question our own assumptions about the language and literacy abilities of learners, be prepared to admit when we need help learning to support students and be willing to challenge ourselves as teachers. At the institutional level, indigenization and internationalization produce unpredictable realities in Canadian HE like that of a South Korean professor teaching a course in an ITEP. To construct equitable learning spaces to better accommodate the multilingual realities of diverse students, Canadian universities must attend to the unpredictability of today's multilingual classrooms in responsive ways, by providing professional support for faculty as instructors.

\section{Examples of Meaningful Engagements with Multilingualism}

As illustrated above, despite the changing context of Canadian HE, university policy and practices continue to encourage or produce English monolingualism (or so-called Standard English). In this section, we share examples of meaningful engagement with multilingualism, understanding these examples as a step toward the development of practices that better reflect the sociolinguistic realities of Canadian universities.

Hyunjung's classroom example is informed by critical pedagogies (Freire, 2000). The L2 Acquisition course for an interdisciplinary Master's TESOL program she taught in 2018 included international students from East Asia, United States, the Middle East, Latin America, and Africa as well as local inservice teachers of settler, immigrant, and Indigenous origin. In the first class, Hyunjung told the class that given the diverse linguistic, cultural, and professional background of the students, she combined oral and written assignments for the course requirements and tried to include at least one reading related to each student's background. She made this pedagogical choice to attend to issues of representation in matters of knowledge production given the unequal representation of certain linguistic and cultural groups prevalent in L2 research and teaching materials. She also mentioned that while students will need to write at a graduate level, she was not looking for "Native-like" English. One international student remarked in her course evaluation that while she was reticent to speak in class due to her anxiety about her English, she also worried that she might be perceived as unmotivated or not hardworking. She commented that when the professor legitimated students' silence by saying that she recognized students' hard work from their assignments, it dispelled her worry and encouraged her to make great efforts in the course.

The next example concerns institutional language policy and demonstrates valuing of Indigenous language in an institutional context in an innovative way. For Canadian graduate students, the choice of language for 
theses and dissertations is largely determined by the thesis guidelines, which serve as a type of language-in-education policy. In Anglophone Canadian universities, graduate students are socialized into the academic tradition of knowledge dissemination in English through course assignment expectations and eventually through graduate theses and dissertations. In many instances, rules about graduate student writing prevent the use of languages other than English. English operates as the de facto or explicitly stated language of graduate theses. Other languages can only be used as exceptions and with approval. As a result, students are cut off from opportunities to draw on all their linguistic resources.

In Andrea's university, the office of graduate studies has recently approved two off-site thesis defenses to be held in Indigenous communities. This, in itself, represents a shift in terms of understanding knowledge mobilization, audience, and commitment to Indigenous communities. In one of these instances, inclusion of Indigenous languages and practices of oracy emerges in a way that Gaudry \& Lorenz (2018) might describe as decolonial indigenization. In this thesis and defense, the student's MEd product was oral, not written, and presented entirely through the medium of nêhiyawêwin (Cree language). Using a panel of nêhiyawak (Cree people) knowledge keepers as external examiners was approved. The university put forward this instance as an approach that better supports the academic and community needs of this student.

\section{Conclusion}

Engaging meaningfully with multilingualism in Canadian HE requires fundamental transformation in the way we think of language, multilingualism, and education as well as a critical understanding of the intersection between English monolingualism and language-related inequalities regarding settler colonialism (Sterzuk, 2011). However, the current time of "settler colonial global present" (Veracini, 2015) is more complicated because of its concurrence with contemporary capitalism, where accountability in education is measured by a set of standardized skills, or competencies, both for students and for teachers (Shin \& Park, 2016; Clarke \& Morgan, 2011). As we illustrate, universities continue to operate in ways that reproduce settler colonial goals of English monolingualism, despite the efforts of well-meaning individual instructors. Responding in ethical ways to the language-related issues created by discourses of internationalization and indigenization will take many forms. The two situations are united in the sense that universities need to work toward supporting learners as they expand plurilingual or multilingual language repertoires. What is different about immigrant or settler languages is that universities are not called to focus on language revitalization efforts. Rather, the challenge is to determine ways for learners to draw on their existing language repertoires by encouraging translanguaging, 
supporting English language development, and being flexible about English language variation.

The global context of Indigenous language revitalization policy includes the Native American Languages Act of 1990 and the United Nations Declaration on the Rights of Indigenous Peoples of 2007. What these policies have in common is a shared declaration of the value of Indigenous languages. As we stated in the introduction, Indigenous students are likely to want to add oral proficiency in the languages of their communities and ancestors. In support of this goal, Canadian universities are called to partner with communities in support of Indigenous language revitalization. This objective may require innovations to the kinds of existing language courses offered in Canadian HE. For instance, an immersion program offered through a partnership between Kwi Awt Stelmexw, a not-for-profit organization from the Squamish Nation community, and Simon Fraser University's (SFU) First Nations Languages Centre and Department of Linguistics is a promising example. This 2-year, full-time, adult immersion program was designed to teach students to become fluent in the Squamish language through 1,000 classroom hours taught exclusively through the medium of the Squamish language (SFU, 2016). Another promising and recent example is a land-based, 3-week, for credit, Michif language camp offered by the Saskatchewan Urban Teacher Education Program (SUNTEP) through a partnership between the Gabriel Dumont Institute and the Faculty of Education at the University of Regina. In the spring of 2019, the course was taught entirely on a small piece of land that is significant to Métis people in Southern Saskatchewan. Métis knowledge keepers and Michif speakers joined students in a camp setting. All activities were conducted on the land and with the assistance of the cultural carriers. Métis Elders and youth participants engaged in the preparation of the campsite and communal meals, the maintenance of the land and buildings of the site, the learning of traditional Michif songs and stories, and the practicing of basic conversations, all in the Michif language (Fayant \& Sterzuk, 2018).

Canadian HE continues to be shaped by contemporary settler colonialism intertwined with global capitalism, which creates common-sense understandings about language, the assumed value of writing over speech, knowledge production, and who has authority. As such, discussions of campus multilingualism need to go beyond conversations of inclusion. If Canadian HE wishes to engage meaningfully with multilingualism, it is first necessary to understand the roots of its rejection. Without this critical dialogue, Canadian universities run the risk of reproducing policies and practices that simply mimic change. We hope our discussion opens up a conversation to engage with a more nuanced understanding of multilingualism, producing collective action among TESL researchers and practitioners to challenge the production of language-related inequality in our daily practices. The very first questions we need to ask may be about the very notion of multilingualism: What kind 
of multilingualism? Whose multilingualism? Why now? For whom? With what consequences?

\section{Acknowledgement}

We sincerely thank the guest editors and anonymous reviewers for their detailed and insightful feedback and suggestions.

\section{The Authors}

Hyunjung Shin is an assistant professor in the Department of Curriculum Studies at the University of Saskatchewan. Her research and teaching centre on globalization, neoliberalism, language, and identity; critical pedagogy and second language (L2) teacher education; and postcolonialism in L2 education.

Andrea Sterzuk is a professor in the Faculty of Education at the University of Regina. Her research projects and teaching focus on issues of power, identity, and language in education, particularly as they relate to settler colonialism.

\section{References}

Altbach, P. G., \& Knight, J. (2007). The internationalization of higher education: Motivations and realities. Journal of Studies in International Education, 11(3-4), 290-305.

Bartell, M. (2003). Internationalization of universities: A university culture-based framework. Higher Education, 45(1), 43-70.

Block, D. (2017). Political economy in applied linguistics research. Language Teaching, 50(1), 32-64.

Bourdieu, P. (1991). Language and symbolic power. Cambridge, MA: Harvard University Press.

Bourdieu, P. (1998). The essence of neoliberalism. Le Monde Diplomatique. Retrieved from http:// mondediplo.com/1998/12/08bourdieu.

Chun, C. W. (2009). Contesting neoliberal discourses in EAP: Critical praxis in an IEP classroom. Journal of English for Academic Purposes, 8(2), 111-120.

Clarke, M., \& Morgan, B. (2011). Education and social justice in neoliberal times: Historical and pedagogical perspectives from two postcolonial contexts. In M. Hawkins (Ed.), Social Justice Language Teacher Education (pp. 63-85). Multilingual Matters.

Darvin, R., \& Norton, B. (2015). Identity and a model of investment in applied linguistics. Annual Review of Applied Linguistics, 35, 64-84.

Delpit, L. (1988). The silenced dialogue: Power and pedagogy in educating other people's children. Harvard Educational Review, 58(3), 280-298.

Duchêne, A., \& Heller, M. (2012). Language in late capitalism: Pride and profit. New York, NY: Routledge.

Fayant, R., \& Sterzuk, A. (2018) Michif language revitalization within a post-secondary context. Canadian Diversity, 15(1). 18-22. https://www.ciim.ca/img/boutiquePDF/ canadiandiversityvol15-no1-2018_mod1-y008j.pdf

Freire, P. (2000). Pedagogy of the oppressed. New York, NY: Continuum.

García, O., \& Wei, L. (2014). Translanguaging: Language, bilingualism and education. New York, NY: Palgrave Macmillan.

Gaudry, A., \& Lorenz, D. (2018). Indigenization as inclusion, reconciliation, and decolonization: Navigating the different visions for indigenizing the Canadian Academy. AlterNative: An International Journal of Indigenous Peoples, 14(3), 218-227.

Gordon, C. E., \& White, J. P. (2014). Indigenous educational attainment in Canada. International Indigenous Policy Journal, 5(3). DOI:10.1 8584/iipj.2014.5.3.6

Harvey, D. (2005). A Brief History of Neoliberalism. Oxford, UK: Oxford University Press.

Haque, E., \& Patrick, D. (2015). Indigenous languages and the racial hierarchisation of language policy in Canada. Journal of Multilingual and Multicultural Development, 36(1), 27-41.

Heller, M. (Ed.). (2007). Bilingualism: A social approach. London: Palgrave Macmillan. 
Heller, M., \& McElhinny, B. (2017). Language, capitalism, colonialism: Toward a critical history. University of Toronto Press.

Holborow, M. (2015). Language and neoliberalism. London, UK: Routledge.

Knight, J. (2004). Internationalization remodeled: Definition, approaches, and rationales. Journal of Studies in International Education, 8(1), 5-31.

Kubota, R. (2009). Internationalization of universities: Paradoxes and responsibilities. The Modern Language Journal, 93(4), 612-616.

Lewis, K., Shirt, M., \& Sylvestre, J. (2018). Looking at the evolution of university of Nuhelot'ine Thaiyots' I Nistamêyimâkanak Blue Quills Language Programmes. In Promising Practices in Indigenous Teacher Education (pp. 237-248). Springer, Singapore.

Loomba, A. (1998). Colonialism/postcolonialism. London: Routledge.

Marshall, S., Hayashi, H., \& Yeung, P. (2012). Negotiating the multi in multilingualism and multiliteracies: Undergraduate students in Vancouver, Canada. Canadian Modern Language Review, $68(1), 28-53$.

Marshall, S. (2009). Re-becoming ESL: Multilingual university students and a deficit identity. Language and education, 24(1), 41-56.

Marshall, S., \& Moore, D. (2013). 2B or not 2B plurilingual? Navigating languages literacies, and plurilingual competence in postsecondary education in Canada. TESOL Quarterly, 47(3), 472-499.

McIvor, O., \& Anisman, A. (2018). 5. Keeping our languages alive: Strategies for Indigenous language revitalization. Handbook of Cultural Security, 90-109.

Motha, S. (2006). Racializing ESOL teacher identities in US K-12 public schools. TESOL Quarterly, 40(3), 495-518.

Ottmann, J. (2017). Canada's Indigenous peoples' access to post-secondary education: The spirit of the "New Buffalo". In J. Frawley, S. Larkin, \& J. A. Smith (Eds.), Indigenous pathways, transitions and participation in higher education (pp. 95-117). Singapore: Springer.

Pennycook, A. (1998). English and the discourses of colonialism. London: Routledge.

Restoule, J. P., Mashford-Pringle, A., Chacaby, M., Smillie, C., Brunette, C., \& Russel, G. (2013). Supporting successful transitions to post-secondary education for Indigenous students: Lessons from an institutional ethnography in Ontario, Canada. The International Indigenous Policy Journal, 4(4), 4.

Shin, H. (2016). Language "skills" and the neoliberal English education industry. Journal of Multilingual and Multicultural Development, 37(5), 509-522.

Shin, H. \& Kubota, R. (2008). Postcolonialism and globalization in language education. In B. Spolsky \& F. M. Hult (Eds.), The Handbook of Educational Linguistics (pp. 206-219). Malden, MA: Blackwell Publishing.

Shin, H., \& Park, J. (2016). Researching language and neoliberalism. Journal of Multilingual and Multicultural Development, 37(5), 443-452.

Simon Fraser University. (2016). New initiative launched at SFU to save Squamish language. SFU News. Retrieved from https://www.sfu.ca/sfunews/stories/2016/new-initiative-launched-atsfu-to-save-squamish-language.html

Smith, L. T. (1999). Decolonizing methodologies: Research and Indigenous Peoples. New York: Zed.

St. Denis, V. (2011). Silencing Aboriginal curricular content and perspectives through multiculturalism: "There are other children here". Review of Education, Pedagogy, and Cultural Studies, 33(4), 306-317.

Sterzuk, A., \& Fayant, R. (2016). Towards reconciliation through language planning for Indigenous languages in Canadian universities. Current Issues in Language Planning, 17(3-4), 332-350. https://doi.org/10.1080/14664208.2016.1201239

Sterzuk, A. (2015). "The standard remains the same": Language standardization, race, and othering in higher education. Journal of Multilingual and Multicultural Development, 36(1), 53-66.

Sterzuk, A. (2011). The struggle for legitimacy: Indigenized Englishes in settler schools. Clevedon, England: Multilingual Matters. 
Thobani, S. (2007). Exalted subjects: Studies in the making of race and nation in Canada. University of Toronto Press.

Truth and Reconciliation Commission of Canada (2015, June). Truth and Reconciliation Commission of Canada: Calls to action. Retrieved from http://www.trc.ca/websites/trcinstitution/File/2015/ Findings/Calls_to_Action_English2.pdf

Tupas, R. (Ed.). (2015). Unequal Englishes: The politics of Englishes today. London: Palgrave Macmillan.

Veracini, L. (2015). The settler colonial present. Springer.

Zappa-Hollman, S., \& Duff, P. (2015). Academic English socialization through individual networks of practice. TESOL Quarterly, 49(2), 333-368. 